\title{
Nordsonne
}

\section{Die Seite für Kinder}

\section{Brigitte Lutz-Westphal}

Im Osten geht die Sonne auf, im Süden nimmt sie ihren Lauf, im Westen will sie untergehn, im Norden ist sie nie zu sehn.

Stimmt das wirklich?

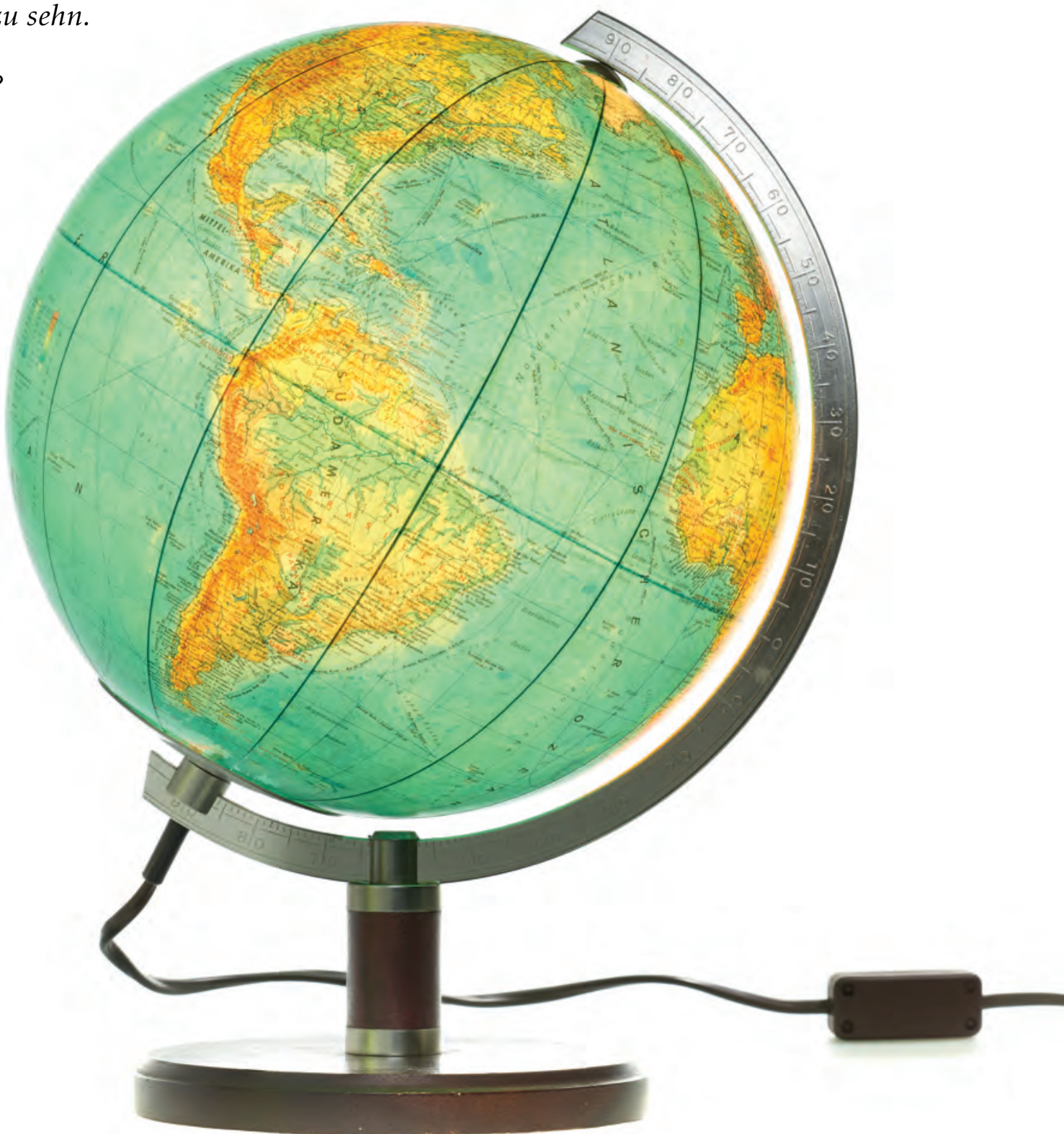

Prof. Dr. Brigitte Lutz-Westphal,

Didaktik der Mathematik, Fachbereich Mathematik und Informatik,

Freie Universität Berlin, Arnimallee 3, 14195 Berlin

brigitte.lutz-westphal@math.fu-berlin.de

(Foto: Christoph Eyrich) 